\title{
PENGARUH METODE LATIHAN SISTEM SIRKUIT TERHADAP PENINGKATAN KEMAMPUAN DAYA LEDAK OTOT LENGAN PADA ATLET BOLABASKET FIK UNP
}

\author{
Sari Mariati ${ }^{1}$, Willady Rasyid ${ }^{2}$ \\ ${ }^{1}$ Program Studi Pendidikan Kepelatihan Olahraga Universitas Negeri Padang. Jalan Prof.Dr.Hamka Air \\ Tawar Barat, Padang, 25132, Indonesia. \\ ${ }^{2}$ Program Studi Pendidikan Olahraga Universitas Negeri Padang. Jalan Prof.Dr.Hamka Air Tawar Barat, \\ Padang, 25132, Indonesia.
}

E-mail: sarimariati@fik.unp.ac.id ${ }^{1}, \underline{\text { Willadirasyid@unp.ac.id }}{ }^{2}$

\begin{abstract}
Abstrak
Penelitian ini bertujuan untuk melihat pengaruh sistem sirkuit terhadap peningkatan daya ledak otot lengan pada atlet FIK UNP Padang. Jenis penelitian ini adalah penelitian exsperimen semu yang dilakukan di GOR PPSP Pembangunan UNP. Sampel penelitian ini adalah pemain bolabasket putra FIK UNP yang berjumlah 10 orang yang diberikan perlakuan 16 kali latihan. Teknik pengambilan data menggunakan two hand medicine ball push. Data yang telah terkumpul digunakan untuk menguji hipotesis yang menggunakan uji t. Sebelum uji t dilakukan terlebih dahulu dilakukan uji persyaratan analisis yaitu uji normalitas dan uji homogenitas. Hasil dari uji hipotesis yang menggunakan statistik uji $t$ dapat disimpulkan sebagai berikut : Sistem sirkuit berpengaruh secara signifikan terhadap peningkatan kemampuan daya ledak otot lengan dapat diperoleh nilai $\mathrm{t}_{\mathrm{hit}} 10.30>\mathrm{t}_{\mathrm{tab}} 2.26$ dan $\mathrm{p} 0.00<0.05 \alpha$
\end{abstract}

Kata Kunci : Sistem sirkuit, kemampuan daya ledak otot lengan pada atlet bolabasket FIK UNP

\section{Abstract \\ Abstract}

This study aims to look at the effect of the circuit system on increasing arm muscle explosive power in UNP Padang FIK athletes. This type of research is a quasi-experimental research conducted at the PPSP GOR of UNP Development. The sample of this research was 10 male basketball players from FIK UNP who were treated 16 times. Data collection techniques using two hand medicine ball push. The collected data is used to test hypotheses using the t test. Before the $t$ test is carried out, the analysis requirements test is carried out, namely the normality test and homogeneity test. The results of hypothesis testing using $t$ test statistics can be summarized as follows: The circuit system has a significant effect on increasing the ability of arm muscle explosive power can be obtained thit 10.30> ttab2.26 and p 0.00 $<0.05 \alpha$.

Keywords : Circuit system, arm muscle explosive ability in basketball athletes FIK UNP.

\section{Pendahuluan}

Menurut PB. PERBASI (2008), permainan bolabasket adalah suatu permainan yang dimainkan oleh dua regu putera atau puteri yang masing-masing regu terdiri dari lima orang pemain dengan menggunakan lapangan permainan berbentuk persegi panjang dengan ukuran $28 \mathrm{~cm} \times 15 \mathrm{~cm}$ dan bola yang terbuat dari karet yang berlapis sejenis kulit dengan keliling $75-78 \mathrm{~cm}$, dengan berat $600-650$ gram.

Adapun waktu permainan bolabasket menurut peraturan PB. PERBASI (2008) adalah
: permainan terdiri dari 4 kuarter yang berdurasi 10 menit, harus ada jeda dari permainan selama 2 menit antara kuarter 1 dan 2 (setengah babak), antara kuarter 3 dan kuarter 4 (satu babak) dan sebelum tiap kuarter tambahan. Harus ada jeda waktu setengah babak dari permainan selama 15 menit dan harus ada jeda waktu dari permainan selama 20 menit sebelum permainan dijadwalkan dimulai.

Sedangkan konsep bermain bolabasket menurut Tomoliyus (2001:11) adalah: menghasilkan skor (nilai) dengan memasukkan bola ke keranjang (basket) dan mencegah tim 
lain melakukan hal serupa. Permainan bolabasket merupakan olahraga yang memiliki aktivitas gerak yang menuntut berbagai keterampilan, teknik dan taktik disamping kondisi yang prima bagi pelakunya. Disamping itu permainan bolabasket menuntut kreativitas teknik, keberanian untuk berbuat sesuatu dan kepercayaan akan kemampuan sendiri dan kerjasama tim yang baik.

Seperti yang dikemukakan oleh Frank S. Pyke dalam PENGDA PERBASI (2005:12) bahwa: "Basketball is a game of habbit, artinya permainan bolabasket adalah olahraga yang berdasarkan kebiasaan".

Dari uraian di atas dimaksudkan bahwa permainan bolabasket adalah olahraga yang berdasarkan kebiasaan, artinya untuk menjadi seorang pemain bolabasket yang baik sangat dibutuhkan proses latihan atau bermain secara berulang-ulang atau berkelanjutan (continue) agar memperoleh teknik, taktik dan kondisi prima dalam permainan yang bagus. Kemudian menurut Bompa dalam Syahara (2005:56) mengemukakan bahwa : untuk menjadi seorang atlet dicabang olahraga bolabasket dapat dimulai dari usia dini yaitu 7-8 tahun. Dalam olahraga permainan bolabasket, usia latihan spesialisasi dimulai pada umur 12-19 tahun, sedangkan usia pencapaian puncak prestasi usia 20-25 tahun, atlet bolabasket lebih matang dalam mengatur strategi dan teknik permainan.

$$
\text { Menurut Witarsyah }
$$

mengatakan bahwa : passing adalah keahlian mendasar yang sangat penting dipelajari oleh setiap pemain bolabasket. Passing merupakan salah satu kunci keberhasilan serangan sebuah tim dan sebuah unsur penentu tembakantembakan yang berpeluang besar mencetak angka. Ketepatan passing yang hebat tidak boleh diremehkan. Ini bisa memotivasi rekan-rekan tim, menghibur penonton dan menghasilkan permainan yang tidak individualis.

$$
\text { Jon dalam Wawan (2007:38) }
$$

mengemukakan bahwa : Dalam passing (mengumpan) dapat dilakukan beberapa macam teknik yaitu : chest pass (umpan dada), bounce pass (umpan pantul), two-handed overhead (umpan atas kepala menggunakan dua tangan), baseball (umpan bisbol/lemparan samping), shuffle pass (umpan sambil berlari), dribble pass (umpan dribble), wrap-around (umpan selubung) dan behind the back (umpan di belakang punggung).

Selanjutnya menurut Wawan (2007:36), mengatakan bahwa : "passing dada (chest pass) adalah umpan yang bisa diandalkan dan dilakukan untuk memindahkan bola dari seorang pemain ke rekan satu timnya, biasanya di bagian daerah perimeter".

Dari kutipan di atas dapat dikemukakan bahwa passing dada (chest pass) merupakan teknik dasar dalam permainan bolabasket dalam usaha memindahkan bola dari satu orang kepada orang yang lain dan dari suatu tempat ke tempat lain pada saat permainan berlangsung. Passing dada (chest pass) dapat dikatakan upaya gerak memindahkan bola dari suatu tempat ke tempat yang lain dan dalam penguasaan pemain yang bersangkutan.

Selanjutnya menurut Sodikoen (1992:49) berpendapat bahwa :

Chest pass (umpan dada dengan dua tangan) merupakan umpan yang sangat bermanfaat (tepat) untuk operan jarak pendek dengan perhitungan demi kecepatan dan kecermatan, bila kawan yang akan menerima tidak dijaga dengan ketat, sedangkan jarak operan yang paling baik untuk lemparan chest pass adalah antara 4-7 meter, tergantung kepada kemampuan daya ledak otot lengan.

Apabila pelaksanaan passing dada (chest pass) berjalan dengan lancar sehingga terciptanya kerjasama tim yang baik dan dapat mengendalikan tempo permainan sehingga mudah untuk menciptakan peluang demi peluang untuk melakukan shooting dan akhirnya poin demi poin terkumpul, maka terciptalah suatu kemenangan. Oleh sebab itu passing dada (chest pass) merupakan salah satu teknik dasar penentu kemenangan di dalam cabang olahraga bolabasket).

Adapun teknik dasar melakukan passing dada (chest pass) menurut Sodikoen (1992:49) adalah sebagai berikut :

1) Sikap kaki berdiri wajar (enak) dengan otot sedikit ditekuk dan badan sedikit condong ke depan (bengkok dan wajar), pandangan ke 
arah lemparan. Kaki boleh sejajar atau satu di depan.

2) Pegang bola dengan kedua telapak tangan dan jari-jari terbuka menutupi bagian samping dan belakang dari bola. Ibu jari hampir mendekat, semua telapak tangan dan jari menyentuh bola.

3) Teknik kedua siku dengan mendekati badan, dan aturlah bola setinggi dada.

4) Operan dimulai dengan melangkahkan satu kaki ke depan ke arah sasaran (sipenerima). Bersamaan dengan melangkahkan kaki, kedua lengan menolak lurus ke depan disertai dengan lekukan pergelangan tangan dan diakhiri dengan jentikan jari-jari.

5) Operan diarahkan setinggi dada si penerima secara mendatar dan bola sedikit berputar.

6) Bersamaan dengan irama gerak pelepasan bola, berat badan dipindahkan ke depan, langkahkan kaki belakang setelah bola lepas dari tangan (sebagai Follow Through).

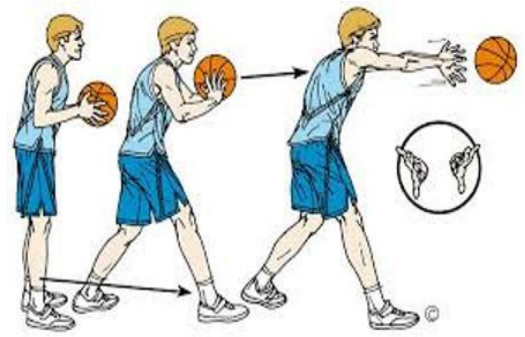

Gambar 1: Bentuk Pelaksanaan Chest pass

(http://www.tutorialolahraga.com)

Hampir semua cabang olahraga memerlukan daya ledak. Untuk itu daya ledak harus diberikan kepada olahragawan dalam usaha meningkatkan prestasi. Dalam melakukan teknik-teknik yang baik khususnya pada cabang olahraga bolabasket sangat dibutuhkan sekali saya ledak yaitu: tenaga yang digunakan pada saat melakukan passing dada (chest pass) atau gerakan mendorong bola kepada teman bermain tim atau melempar bola sejauh mungkin.

Menurut Bompa dalam Syahara (2004: 20-23) daya ledak (power) merupakan hasil dari dua kemampuan yaitu kekuatan dan kecepatan dan dipertimbangkan sebagai suatu kemampuan untuk menampilkan kekuatan yang maksimum dalam waktu yang paling pendek.

Daya ledak otot lengan merupakan kemampuan dasar kondisi fisik yang merupakan tumpuan utama dalam pencapaian prestasi bolabasket, khususnya dalam melakukan passing dada (chest pass). Perolehan poin (angka) tidak akan dapat tercipta apabila passing dada (chest pass) yang dilakukan tidak sampai atau berjalan dengan lancar kepada pemain yang berada pada posisi bebas untuk melakukan shooting ke ring basket. Passing dada (chest pass) merupakan salah satu teknik dasar dalam menyusun strategi penyerangan.

Dari pendapat di atas dapat dikemukakan bahwa otot harus menerapkan tenaga dengan kuat dalam waktu yang sangat singkat untuk memberikan momentum yang paling baik pada tubuh atau objek untuk membawa ke jarak yang diinginkan. Dalam penelitian ini daya ledak otot yang dimaksudkan adalah daya ledak otot lengan dimana komponen ini sangat penting dalam olahraga bolabasket, terutama pada saat melakukan passing dada (chest pass) yang merupakan jenis daya ledak skill.

Janssen dalam Asril

(1999:72) menyatakan bahwa :

Daya ledak adalah semua gerakan eksplosif yang maksimum secara langsung tergantung pada daya otot, dimana sangat penting untuk menampilkan prestasi yang tinggi. Apabila seorang pemain bolabasket memiliki daya ledak otot lengan yang baik akan dapat menampilkan prestasi yang tinggi dimana penampilan pemain menjadi lebih baik khususnya pada kemampuan passing dada (chest pass). Sebaliknya, apabila seorang pemain bolabasket memiliki daya ledak yang tidak baik akan dapat mempengaruhi prestasinya dimana penampilan pemain menjadi menurun.

Kemudian Bompa dalam Bafirman (1999:59) menyatakan bahwa :

Daya ledak menurut macamnya ada dua, yaitu daya ledak absolut berarti 
kekuatan untuk mengatasi suatu beban eksternal yang maksimum, sedangkan daya ledak relatif berarti kekuatan yang digunakan untuk mengatasi beban berupa berat badan sendiri. Daya ledak akan berperan apabila dalam suatu aktivitas olahraga terjadi gerakan eksplosif.

Tanpa memiliki daya ledak otot lengan yang baik akan mempengaruhi jauhnya lemparan, luncuran serta mempengaruhi kecepatan lajunya bola sehingga memakan waktu yang cukup lama untuk sampai kepada rekan satu tim yang akan menerima bola sehingga cenderung bola tidak sampai tepat pada sasaran atau dapat dihalangi atau ditangkap oleh tim lawan bermain. Oleh sebab itu, apabila daya ledak otot lengan yang dimiliki sebuah tim (pemain) bolabasket tidak bagus, maka hal ini dapat menjadikan halangan bagi tim tersebut untuk meraih prestasi yang maksimal.

Hal terpenting yang bagus dilakukan dalam menghasilkan passing dada (chest pass) yang baik adalah pengumpan harus mengetahui posisi rekan satu tim yang akan menerima umpan (bola) dan harus mempunyai keseimbangan posisi yang baik sebelum melempar bola (passing dada), kemudian bahu dan lengan harus bebas untuk bergerak dengan bantuan daya ledak. a. Otot-otot yang terlibat dalam gerakan chest pass.

a. Otot-otot yang terlibat dalam gerakan chest pass

Adapun otot-otot lengan yang sangat berperan sekali dalam melakukan passing dada (chest pass) pada cabang olahraga permainan bolabasket menurut Basoeki (1988:28) dapat dilihat pada gambar di bawah ini :

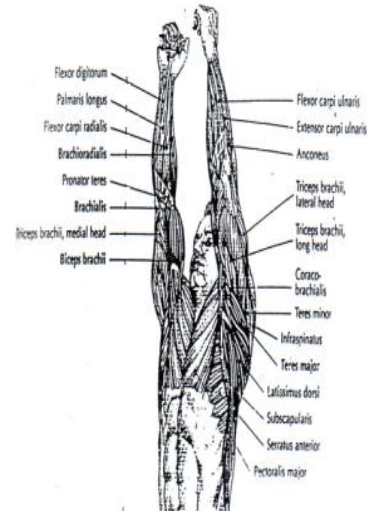

Gambar 2: Otot-otot lengan yang dominan digunakan dalam pelaksanaan passing (Delavier, 2001 : 63)

\section{b. Sistem Energi}

Syahara (2004:1) menyatakan bahwa seluruh energi yang dipakai dalam dunia biologis pada dasarnya bersumber dari matahari. Sumber energi yang dapat dengan segera digunakan untuk setiap aktivitas manusia seperti pada sistem biologis datang dari pemecahan senyawa kimia tunggal $\rightarrow$ ATP (Adenosine Triphospate). Metabolisme produksi ATP otot dan sel berasal dari pembebasan energi melalui pemecahan zat makanan dan senyawa lain yang melibatkan serangkaian reaksi kimia anaerobik maupun aerobik (karbohidrat, selulosa, protein dan lemak). Untuk otot yang bekerja, maka sistem energinya tergantung dari intensitas dan jangka waktu yang digunakan dalam kegiatan yang dilakukan.

Nawawi (2008:1) membagi sumber dan bentuk energi yang ada ke dalam beberapa bagian, yaitu : 1) energi matahari, 2) energi listrik, 3) energi mekanik, 4) energi kimia, 5) energi potensial, dan 6) energi nuklir (atom).

Berdasarkan kutipan-kutipan di atas sumber energi yang paling utama akan mempengaruhi proses yang lain adalah energi yang berasal dari matahari. Energi kimia dapat diubah menjadi energi mekanik yang akan menghasilkan gerak. Untuk melakukan berbagai aktivitas tubuh memerlukan gerak, gerak dihasilkan dari kontraksi dan relaksasi otot rangka, untuk bisa bekerja otot rangka memerlukan energi, energi diambil dari pemecahan bahan kimia di dalam otot yaitu ATP (Adenosine Triphosphate).

c. Ciri-ciri latihan (power) daya ledak Harsono (1993:13-14) mengatakan:

1) Melawan beban berat badan sendiri atau tambahan beban luarrelatif ringan.

2) Gerakan latihan dinamis dan cepat.

3) Gerakan merupakan gerakan yang utuh, singkat dan harmonis.

4) Bentuk bahan latihan cyclic atau acyclic.

5) Intensitas sub maksimal atau maksimal.

d. Prinsip - prinsip yang harus diperhatikan dalam latihan daya ledak menurut Harsono (1993: 14) adalah: 
1) Volume beban latihan dalam 1 sesi latihan $4-6$ set.

2) Intensitas submaksimal atau maksimal, beban yang diangkat (berat barbell) $1 / 4$ $1 / 3$ berat badan atlet.

3) Ulangan angkatan per - set 12-15 kali.

4) Recovery antar set $2-3$ menit.

\section{Hakekat Metode Latihan}

Latihan adalah aktivitas atau kegiatan yang terdiri dari berbagai bentuk sikap dan gerak, terarah, berulang-ulang, dengan beban yang kian bertambah guna memperbaiki efisiensi kemampuan. Menurut Bompa (1994:2) "latihan merupakan proses pengulangan yang sistematis, progresif dengan tujuan akhir memperbaiki prestasi olahraga. Kunci utama dalam memperbaiki prestasi olahraga adalah sistem latihan yang diorganisasikan secara baik. Program latihan harus mengikuti konsep periodesasi, disusun dan direncanakan secara baik berdasar cabang olahraga, agar sistem energi atlet mampu beradaptasi terhadap kekhususan cabang olahraga".

Menurut Rothig dan Grossing dalam Syafruddin (2004:24) "memilih bentuk-bentuk latihan merupakan hal yang penting dalam usaha peningkatan prestasi atlet pada setiap cabang olahraga". Efektifitas bentuk-bentuk latihan untuk mengoptimalkan prestasi olahraga yang komplek (kemampuan kondisi) ditentukan oleh perbandingan komponen-komponen beban serta aturan-aturannya.

Oleh sebab itu bagi setiap pelatih dan pembina olahraga dalam memberikan latihan harus mengggunakan metode latihan, karena dengan menggunakan metode latihan maka setiap pelatih dan pembina olahraga dalam memberikan latihan haru menggunakan metode latihan, karena dengan menggunakan metode latihan maka latihan dapat direncanakan dan dilaksanakan sesuai dengan tujuan dan kondisi yang ada.

Metode latihan menurut Syafruddin (1996:104) adalah cara-cara yang digunakan secara terencana dan sistimatis dan terorientasi pada tujuan. Bachtiar (1995:19) menambahkan bahwa metode latihan adalah cara mengajarkan khusus yang digunakan dalam mengelola pengetahuan prinsip-prinsip dan norma-norma yang berlaku dalam olahraga atau semua yang penting dalam proses belajar motorik untuk tercapainya tujuan dan keefektifan dalam belajar.

Dari pengertian-pengertian di atas terlihat bahwa tujuan memegang peranan penting dalam menetapkan dan memilih metode latihan yang akan digunakan. Tujuan latihan yang jelas dan tepat akan membantu dalam merencanakan kegiatan latihan, salah satunya adalah membantu penggunaan metode dalam kegiatan latihan yang dilakukan (IAAF dalam Syafruddin, 1999:86). Dengan demikian dapat disimpulan bahwa fungsi dari suatu metode adalah sebagai alat untuk mencapai tujuan yang hendak dicapai. Makin baik suatu metode semakin efektif pula dalam pencapaian tujuan latihan.

\section{Metode Latihan Sistem Sirkuit}

Metode latihan sistem sirkuit yang pertama kali diperkenalkan oleh Morgan dan Adamson pada tahun 1953 di Universitas of Leed di Inggris. Sejak diperkenalkannya sistem latihan ini menjadi sangat populer dan ini dilihat dari banyaknya pelatih dan pembina yang menggunakan sistem ini dalam metode latihan yang mereka rancang dan mereka pakai dalam pencapaian prestasi (Sodikoen, 1991:6).

Sistem sirkuit menurut Fox dalam Yendrizal (1997:24) adalah latihan yang terdiri dari 6 - 15 pos tempat latihan. Satu kali latihan dalam stasiun diselesaikan dalam waktu 30 detik, satu sirkuit diselesaikan antara $5-20$ menit dan istirahat tiap pos adalah 5 - 20 detik. Menurut Sodikoen (1991:62) bentuk latihan sirkuit disusun dalam bentuk lingkaran, mulai dari pos I, II, III dan seterusnya disusun berurutan mengelilingi arena (lapangan). Dalam latihan sirkuit atlet harus melalui pos demi pos yang telah ditentukan dan tidak boleh melampaui pos berikutnya. Selanjutnya Soedikoen (1991:65) kembali menjelaskan satu sirkuit telah dianggap selesai apabila atlet telah menyelesaikan latihan di setiap pos sesuai dengan target waktu yang telah ditetapkan.

Menurut Sajoto (1988:161) satu sirkuit latihan dinyatakan selesai, apabila seseorang telah menyelesaikan semua pos sesuai dengan dosis yang telah ditetapkan. Bentuk-bentuk 
latihan sirkuit ini biasanya adalah kombinasi dari semua unsur kondisi fisik sehingga diasumsikan dapat mengembangkan kekuatan, daya tahan, kelincahan dan lain-lain.

Keuntungan berlatih sistem sirkuit menurut Harsono dalam Yendrizal (1997:26) adalah :

1) Meningkatkan berbagai komponen kondisi fisik secara serentak dengan waktu yang relatif singkat,

2) Setiap atlet dapat berlath menurut kemajuannya masing-masing,

3) Setiap atlet dapat mengobservasi dan menilai kemajuannya masing- masing,

4) Latihan mudah diawasi, dan

5) Hemat waktu karena waktu relatif singkat dapat menampung banyak orang

berlatih sekaligus.

Jadi dapat disimpulkan bahwa metode latihan sistim sirkuit adalah program latihan yang telah disusun sedemikian rupa, terdiri dari beberapa pos. Latihan selesai apabila atlet sudah melalui pos-pos secara berurutan. Saat perpindahan pos diselingi dengan interval atau istirahat sesuai dengan waktu yang telah ditetapkan, sedangkan istirahat satu set dilakukan selama 2 menit dan istirahat yang dipakai adalah istirahat aktif.

Pada metode latihan sistem sirkuit, bentuk latihan kondisi fisik untuk teknik pelaksanan latihan tidak cara pelaksanaan tidak berbeda dengan sistem set, namun pada sistem ini atlet diharuskan menyelesaikan bentuk latihan pada satu pos kemudian pindah pada pos berikutnya pada pos terakhir. Setiap atlet harus melaknanakan gerakan disetiap pos secara berurutan . setelah menyelesaikan 1 set kemudian istirahat dan melakukan kembali hingga sampai 3 set. Jadi,secara sederhana metoda latihan sistem sirkuit dapat digambarkan yaitu $10 \times 3$ set (jumlah pos $\times$ jumlah set) .dengan cara latihan seperti ini akan terjadi pengaruh pada peningkatan kondisi fisik atlet yang mendukung kemampuan chest pass pada bolabasket tepatnya sistem sirkuit diharapkan dapat memberi pengaruh pada peningkatan kemampuan daya ledak otot lengan pada atlet bolabasket.

\section{Metode Penelitian}

Jenis yang digunakan dalam penelitian ini adalah penelitian eksperimen semu Penelitian ini dilaksanakan di GOR PPSP Pembangunan UNP. Populasi penelitian ini adalah atlet-atlet tim B putera bolabasket Fakultas Ilmu Keolahragaan UNP yang berusia 19-24 tahun yang berjumlah 10 orang. Instrumen dilakukan dengan melakukan tes terhadap pemain bolabasket yang dijadikan sampel. Tes dilakukan dengan cara mengukur kemampuan daya ledak otot lengan yaitu dengan tes "two hand medicine ball-push" (Nurhasan, 1984 : 57), dengan koefisien realibilitas tes sebesar 0,81 dan validitas 0,77 serta objektivitas 0,99 .

Pendeskripsian data dan pengujian hipotesis dalam penelitian ini diolah dengan memakai statistik deskriptif dan inferensial dengan rumus uji $t$ sampel terikat. Sebelum dilakukan analisis uji $t$, terlebih dahulu dilakukan uji persyaratan analisis, yaitu normalitas data dan homogenitas, dan uji t hanya dapat digunakan untuk menguji perbedaan mean dari dua tes yang diambil dari populasi yang normal dan kelompok yang homogen (Isparjadi : 1998).

Setelah uji normalitas dilakukan, maka dilakukan analisis uji t, dengan rumus sebagai berikut :

$$
\mathrm{t}=\frac{\left|\overline{\mathrm{X}_{1}}-\overline{\mathrm{X}_{2}}\right|}{\sqrt{\frac{\Sigma \mathrm{D}^{2}-\frac{(\Sigma \mathrm{D})^{2}}{\mathrm{~N}}}{\mathrm{~N}(\mathrm{~N}-1)}}}
$$

Keterangan :

$\mathrm{t}=$ Harga uji $\mathrm{t}$ yang dicari

$\overline{\mathrm{X}}_{1}=$ Mean tes awal

$\overline{\mathrm{X}}_{2}=$ Mean tes akhir

$\mathrm{D}=$ Beda antara skor tes awal dan akhir

$\mathrm{N} \quad=$ Pasangan

Df $\quad=$ Derajat kebebasan $(\mathrm{df})=\mathrm{N}-1$

$\sum \mathrm{D}=$ Jumlah semua beda

$\sum \mathrm{D}^{2}=$ Jumlah semua beda yang dikuadratkan (Isparjadi, 1988:57)

\section{Hasil Penelitian dan Diskusi}

Data dalam penelitian ini merupakan data primer yaitu daya ledak otot lengan yang diukur 
dengan menggunakan bola medisin (medicine ball).

Tabel 3. Deskripsi Data Daya Ledak Otot Lengan Sistem Sirkuit

\begin{tabular}{|c|c|c|c|}
\hline \multirow[b]{2}{*}{ NO. } & \multicolumn{2}{|c|}{ SISTIM SIRKUIT } & \multirow[b]{2}{*}{ NAMA } \\
\hline & $\begin{array}{l}\text { PRE- } \\
\text { TEST }\end{array}$ & $\begin{array}{c}\text { POST- } \\
\text { TEST }\end{array}$ & \\
\hline 1. & $5.3 \mathrm{mtr}$ & $5.6 \mathrm{mtr}$ & ANTON \\
\hline 2. & $5 \mathrm{mtr}$ & $5.5 \mathrm{mtr}$ & KOMET \\
\hline 3. & $4.8 \mathrm{mtr}$ & $5.2 \mathrm{mtr}$ & ANDIKA \\
\hline 4. & $4.6 \mathrm{mtr}$ & $5 \mathrm{mtr}$ & YUVIA \\
\hline 5. & $4.3 \mathrm{mtr}$ & $4.5 \mathrm{mtr}$ & RURY \\
\hline 6. & $4.2 \mathrm{mtr}$ & $4.5 \mathrm{mtr}$ & AZHARI \\
\hline 7. & $4.2 \mathrm{mtr}$ & $4.5 \mathrm{mtr}$ & ERY \\
\hline 8. & $4.1 \mathrm{mtr}$ & $4.5 \mathrm{mtr}$ & DAVID \\
\hline 9. & $3.9 \mathrm{mtr}$ & $4.5 \mathrm{mtr}$ & NICO \\
\hline 10. & $3.5 \mathrm{mtr}$ & $4 \mathrm{mtr}$ & FERRY \\
\hline \multicolumn{2}{|c|}{$43.9 \mathrm{mtr}$} & $47.8 \mathrm{mtr}$ & $\sum$ \\
\hline
\end{tabular}

Selanjutnya data-data tersebut di atas dianalis dengan statistik deskriptif, dan hasilnya dapat dilihat pada tabel berikut ini;

Tabel 4. Statistik Deskriptif Data Penelitian

\begin{tabular}{|l|r|r|r|r|r|r|r|}
\hline & $\mathrm{N}$ & $\begin{array}{r}\text { Minim } \\
\text { um }\end{array}$ & $\begin{array}{r}\text { Maxi } \\
\text { mum }\end{array}$ & Sum & Mean & & $\begin{array}{r}\text { Std. } \\
\text { Deviatio } \\
n\end{array}$ \\
\hline & $\begin{array}{r}\text { Stati } \\
\text { stic }\end{array}$ & $\begin{array}{r}\text { Statist } \\
\text { ic }\end{array}$ & $\begin{array}{r}\text { Stati } \\
\text { stic }\end{array}$ & $\begin{array}{r}\text { Statist } \\
i c\end{array}$ & $\begin{array}{r}\text { Statisti } \\
\text { c }\end{array}$ & $\begin{array}{r}\text { Std. } \\
\text { Erro } \\
r\end{array}$ & Statistic \\
\hline $\begin{array}{l}\text { DOL AWAL } \\
\text { SISTIM CIRCUIT }\end{array}$ & 10 & 3.5 & 5.3 & 43.9 & 4.390 & .170 & .538 \\
\hline $\begin{array}{l}\text { DOL AKHIR } \\
\text { SISTIM CIRCUIT }\end{array}$ & 10 & 4.0 & 5.6 & 47.8 & 4.780 & .164 & .518 \\
\hline Valid N (listwise) & 10 & & & & & & \\
\hline
\end{tabular}

Berdasarkan pada tabel di atas dapat dilihat bahwa: perlakuan sistem sirkuit memiliki nilai tertinggi pada tes awal adalah 5.3 meter, nilai terendah 3.5 meter, dan nilai rata-ratanya 4.39 meter. Selanjutnya setelah diberikan perlakuan dengan memakai sistem sirkuit memperoleh nilai tertinggi 5.6 meter, nilai terendah 4.0 meter, dan nilai rata-ratanya adalah 4.78 meter. Dengan demikian dapat disimpulkan bahwa terdapat peningkatan daya ledak otot lengan setelah diberikan perlakuan.

\section{A. Pengujian Hipotesis}

Sebelum melakukan pengujian sitem sirkuit $\left(\mathrm{X}_{1}\right)$ terhadap terhadap peningkatan kemampuan daya ledak otot lengan pada atlet bolabasket fik unp (Y) terlebih dahulu dilakukan uji persyaratan analisis yaitu uji normalitas sebaran data. Setelah data diuji dengan persyaratan analisis dilakukan uji Hipotesis.

\section{Uji Normalitas}

Uji normalitas data menggunakan Kolmogorov-Smirnov $\mathrm{Z}$ test, dan hasil yang diperoleh menunjukan bahwa data berdistribusi normal yaitu $p>\alpha 0.05$. Untuk lebih jelasnya dapat dilihat pada tabel di bawah ini;

Tabel 5. Uji Normalitas Data

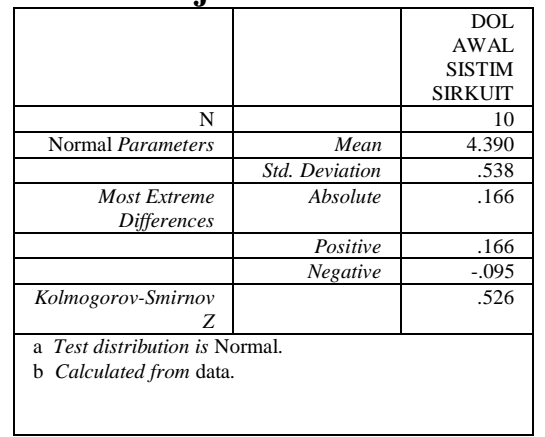

\section{Uji Homogenitas}

Hasil uji homogenitas data dengan melalui uji varians, memperlihatkan bahwa data memiliki keragaman yang tidak berbeda dengan $p>\alpha$ 0.05. Dengan demikian dapat disimpulkan bahwa data awal berada dalam keadaan homogen.

Tabel 6. Uji Hemogenitas Varians Data Penelitian

Test of Homogeneity of Variances

\begin{tabular}{|r|r|r|r|}
\hline $\begin{array}{r}\text { Levene } \\
\text { Statistic }\end{array}$ & df1 & df2 & Sig. \\
\hline .118 & 1 & 18 & .735 \\
\hline
\end{tabular}

\section{Uji Hipotesis}

Terdapat pengaruh yang signifikan latihan sistem sirkuit terhadap peningkatan daya ledak otot lengan

Hasil analisis menunjukan bahwa; latihan sistem sirkuit dapat meningkatkan daya ledak otot lengan secara bermakna, yaitu $\mathrm{t}_{\text {hit }} 10.14>\mathrm{t}_{\text {tab }} 2.26$ dan $p 0.000<\alpha$ 0.05 . Ini dapat diartikan bahwa terdapat 
perbedaan yang signifikan antara hasil tes awal dengan hasil tes akhir setelah diberikan perlakuan latihan sistem sirkuit. Hasil analisis tersebut dapat dilihat pada tabel di bawah berikut;

\section{Tabel 8. Uji t DOL Awal dan Akhir Sistem} Sirkuit

Paired Samples t-test

\section{Pembahasan}

Sistem sirkuit merupakan salah satu bentuk latihan yang telah disusun sedemikian rupa, dimana atlet diharuskan menyelesaikan bentuk latihan pada satu pos kemudian pindah pada pos berikutnya sampai pos terakhir. Setelah menyelesaikan 1 set kemudian istirahat dan melakukan kembali sampai 3 set.

Daya ledak merupakan salah satu dari komponen biomotorik yang penting dalam kegiatan olahraga, karena daya ledak akan menentukan seberapa jauh melempar bola, sehingga otot harus mengerahkan tenaga dengan kuat dalam waktu yang singkat untuk memberikan momentum yang paling baik pada tubuh atau objek untuk membawa ke objek yang diinginkan.

Setelah dilakukan analisis data terhadap hasil penelitian dengan menggunakan analisis uji t terhadap hipotesis yang diajukan teruji secara empiris. Temuan penelitian seperti yang dikemukakan di atas merupakan hasil analisis secara statistic dan perlu dikaji sebagai berikut:

\section{Sistem sirkuit memberikan pengaruh yang signifikan terhadap peningkatan daya ledak otot lengan.}

Berdasarkan hasil pengujian hipotesis(2) menunjukkan bahwa latihan sistim sirkuit dapat meningkatkan daya ledak otot lengan. Dengan nilai thit $10,30>$ ttab 2,26 dan p $0,00<\alpha 0,05$ hal ini disebabkan orang coba melakukan gerakan secara serius dan juga masa istirahat dari pos kepos yang hanya 30 detik sehingga tampak terlihat peningkatan secara berarti.

Sesuai dengan prinsip latihan yang dikatan oleh (Fox 1988:25) suatu proses yang sistematis dalam menyiapkan atlet pada penampilan tingkat tinggi, proses dilakukan berulang-ulang dengan beban semakin meningkat. Dengan demikian dapat dikatakan latihan sisitim sirkuit dat meningkatkan daya ledak otot lengan.

\section{Kesimpulan}

Berdasarkan analisis data dan pembahasan di atas, maka penelitian dapat disimpulkan sebagai berikut: Sistem sirkuit memberikan pengaruh yang signifikan terhadap peningkatan daya ledak otot lengan dengan nilai $t_{\text {hit }} 10.30>$

\begin{tabular}{l|r|r|r|r|r|r|}
\multicolumn{1}{c|}{$\mathrm{t}_{\text {tab }} 2$} \\
.26 \\
\cline { 2 - 7 } \\
dan & Pair 1 & DOL AWAL & $\mathrm{N}$ & Correlation & Sig. & $\mathrm{t}$ \\
$\mathrm{p}$ & & DAN AKHIR & & .972 & .000 & 10.142 \\
& & SISTIM & & & & \\
\hline & SIRKUIT & & & & \\
\hline
\end{tabular}
$0.00<0.05 \alpha$.

\section{DAFTAR PUSTAKA}

Arsil. (1999). Pembinaan Kondisi Fisik. Padang: FIK UNP.

Bafirman \& Apri Agus. (1999). Pembinaan Kondisi Fisik. Padang: FIK UNP.

Basoeki, Soejono. (1988). Anatomi dan Fisiologi Manusia. Jakarta : Depdikbud.

Bompa, Tudor O. (1994). Power Training for Sport. Canada : Mocaic Press.

Delavier, Frederic (2001). Strength Training Anatomy. Canada : Publishing of Human Kinetic.

Harsono (1993) Prinsip-prinsip Pelatihan. Jakarta: P2LPTK.

Http://www.tutorialolahraga.com/2015/08/penge rtian-chest-pass.html

Isparjadi (1988). Statistik Pendidikan. Jakarta : Depdikbud, Dikti : P2 LPTK.

Nawawi, Umar. (2008). Fisiologi Olahraga. Padang : FIK UNP. 
Nurhasan. (1984). Tes dan Pengukuran Pendidikan Olahraga. Bandung : FPOK IKIP Bandung.

PB. PERBASI (2005). Bahan Penataran dan Penyegaran Bagi Pelatih Tingkat Dasar. Padang : Pengda Perbasi Sumbar.

PB. PERBASI .(2008). Pengaturan Permainan Bola Basket. Jakarta : PERBASI.

Sajoto, Mochammad. (1988). Pembinaan Kondisi Fisik. Semarang: FPOK IKIP Semarang.

Sodikoen, Imam. (1991). Pembinaan Prestasi Bolabasket di PGSD. Jakarta: P2TK Dirjen Dikti Dikbud.

Sodikoen, Imam. (1992). Olahraga Pilihan Bolabasket. Padang : FPOK IKIP Padang.

Syafruddin. (1996). Pengantar Ilmu Melatih. Padang : FPOK IKIP Padang.

Syafruddin (2004). Pengantar Ilmu Melatih. Padang : FIK UNP Padang.

Syahara, Sayuti. (2004). Kemampuan Biomotorik dan Metodologi Pengembangan (terjemahan). Padang: FIK UNP Padang.

Syahara, Sayuti. (2005). Fisiologi Olahraga. Padang: Konsentrasi Manajemen Pendidikan Olahraga Pascasarjana UNP.

Tomoliyus. (2001). Pendekatan Keterampilan Taktis dalam Pembelajaran Bola Basket. (konsep dan metode). Jakarta : Depdiknas Dirjen Pendidikan Dasar dan Menengah dan Dirjen Olahraga.
Wawan Eko Yulianto. (2007). Dasar-dasar Bola Basket (terjemahan). Bandung : Pakar Raya.

Witarsyah. (2005). Bola Basket Pendalaman. Padang : FIK UNP.

Yendrizal. (1997). Pengaruh Latihan Beban dan Kemampuan Motorik Otot terhadap Kekuatan Otot. Tesis. Jakarta. 